\title{
HUBUNGAN ANTARA MOTIVASI BERPRESTASI, KEBIASAAN BELAJAR, DAN PENGGUNAAN MEDIA PEMBELAJARAN DENGAN KOMPETENSI GURU IPA MTS PASCA DIKLAT
}

\author{
Oleh: \\ Intan Pulungan \\ Balai Diklat Keagamaan \\ Email: intanpulungan25@yahoo.com
}

\begin{abstract}
ABSTRAK
Tujuan dilaksanakannya penelitian ini adalah untuk menjelaskan hubungan antara: motivasi berprestasi, kebiasaan belajar, penggunaan media pembelajaran dengan kompetensi guru IPA Madrasah Tsanawiyah. Metode penelitian yang digunakan adalah metode survey, dengan teknik analisis korelasional. Koefisien korelasi untuk hubungan antara kedua variabel ini adalah sebesar 0,539. Persamaan garis regresi yang diperoleh adalah $\hat{Y}=41,2+0,19 \mathrm{X}_{1}$. Hal ini menunjukkan bahwa semakin tinggi motivasi berprestasi guru maka akan semakin meningkatkan kompetensinya. Terdapat hubungan yang positif antara Kebiasaan Belajar dengan kompetensi guru IPA Madrasah Aliyah. Koefisien korelasi untuk hubungan antara kedua variabel ini adalah sebesar 0,509. Persamaan garis regresi yang diperoleh adalah $\hat{Y}=44,31+0,1 X_{2}$. Terdapat hubungan yang positif antara penggunaan media pembelajaran dengan kompetensi guru IPA Madrasah Aliyah. Koefisien korelasi untuk hubungan antara kedua variabel ini adalah sebesar 0,5485. Persamaan garis regresi yang diperoleh adalah $\hat{Y}=44,80+0,11 \mathrm{X}_{3}$. Terdapat hubungan yang positif antara motivasi berprestasi, kebiasaan belajar dan penggunaan media pembelajaran secara bersama-sama dengan kompetensi guru kimia Madrasah Aliyah. Koefisien korelasi untuk hubungan antara keempat variabel ini adalah sebesar 0,652. Persamaan garis regresi yang diperoleh adalah $Y=36,36+0,160 X_{1}+0,003 X_{2}+0,082 X_{3}$. Kesimpulannya semakin baik motivasi berprestasi, kebiasaan belajar dan penggunaan media pembelajaran secara bersama-sama maka akan semakin meningkatkan kompetensi guru.
\end{abstract}

Kata Kunci : Motivasi, Kebiasaan Belajar, Media Pembelajaran, Kompetensi Guru IPA 


\section{ABSTRACT}

The purpose of this study is to explain the relationship between: achievement motivation, study habits, use of learning media with the competence of science teachers Madrasah Tsanawiyah. The research method used is survey method, with correlation analysis technique. The correlation coefficient for the relationship between these two variables is 0.539 . Equation of obtained regression line is $\hat{Y}=41,2+0,19 X_{1}$. This shows that the higher the achievement motivation of the teacher will increase their competence. There is a positive relationship between the Habits of Learning with the competence of science teachers Madrasah Aliyah. The correlation coefficient for the relationship between these two variables is 0.509. Equation of regression line obtained is $\hat{Y}=44,31+0,1 X_{2}$. There is a positive relationship between the use of learning media with the competence of science teachers Madrasah Aliyah. The correlation coefficient for the relationship between these two variables is 0.5485 . Equation of regression line obtained is $\hat{Y}$ $=44,80+0,11 X_{3}$. There is a positive relationship between achievement motivation, learning habits and the use of learning media together with the competence of chemical teachers Madrasah Aliyah. The correlation coefficient for the relationship between these four variables is 0.652 . The regression line equation obtained is $\hat{Y}=36,36+0,160 X_{1}+0,003 X_{2}+0,082$ $X_{3}$. The conclusion the better achievement motivation, learning habits and the use of learning media together will further enhance the competence of teachers.

\section{Keywords: Motivation, Habit of Learning, Learning Media, Competence of Science Teachers}

\section{PENDAHULUAN}

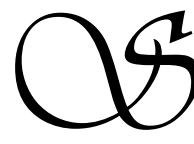

aat ini kita sedang berada dalam abad 21, yang ditandai dengan ciri-ciri: (1) dunia tanpa batas, (2) kemajuan ilmu pengetahuan dan teknologi serta aplikasinya di dalam kehidupan manusia, (3) kesadaran terhadap hak dan kewajiban asasi manusia, kerjasama dan. kompetisi antar bangsa (Tilaar, 2002:2-4). Terkait dengan era global tersebut pada awal tahun 2003 Asean Free Trade Area (AFTA) telah dimulai dan itu adalah sinyalemen utama sangat dibutuhkannya sumber daya manusia yang berkualitas guna berkompetisi di era global, dan permintaan pelayanan jasa tak hanya terbatas pada wilayah lokal, dengan artian para pengguna jasa lebih membutuhkan sumber daya manusia yang berkualitas baik dari dalam maupun dari luar negeri. 
Sehubungan dengan hal tersebut di atas. maka diperlukan adanya sumber daya manusia yang handal dan dapat menghadapi tantangan, menciptakan serta mengisi peluang, karena berdasarkan pengalaman salah satu penyebab terjadinya krisis ekonomi adalah rendahnya kualitas sumber daya manusia. Oleh karena itu, diperlukan strategi pengembangan sumber daya manusia Indonesia dalam menghadapi tantangan dan peluang global, dan salah satu upaya untuk meningkatkan sumber daya manusia itu adalah pendidikan.

Pelaksanaan pendidikan tersebut dilaksanakan dalam tiga lingkungan pendidikan yaitu pendidikan formal, informal, dan non formal. Ketiga lingkungan pendidikan secara bersama-sama membina sumber daya manusia sesuai dengan yang ditetapkan/ diharapkan. Dari ketiga lingkungan pendidikan tersebut, maka pendidikan formal mempunyai tugas dan peran yang terpenting, khususnya dalam membekali berbagai ilmu pengetahuan dasar yang diperlukan dalam kehidupan manusia.

Lembaga pendidikan formal sebagaimana dikemuka-kan dalam pasal 14 Undang-Undang Sistem Pendidikan Nomor 20 Tahun 2003 bahwa jenjang pendidikan formal terdiri atas pendidikan dasar, pendidikan menengah, dan pendidikan tinggi. Selanjutnya dalam pasal 16 disebutkan: Jalur, jenjang dan jenis pendidikan dapat diwujudkan dalam bentuk satuan pendidikan yang diselenggarakan oleh Pemerintah, Pemerintah Daerah, dan/atau masyarakat. Dalam pasal 39 ayat (1) disebutkan bahwa: Tenaga kependidikan bertugas melaksanakan administrasi, pengelolaan, pengembangan, pengawasan, dan pelayanan teknis untuk menunjang proses pendidikan pada satuan pendidikan. Dalam ayat (2) disebutkan: Pendidik merupakan tenaga profesionai yang bertugas merencanakan dan melaksanakan proses pembelajaran, menilai hasil pembelajaran, melakukan pembimbingan dan pelatihan, seita melakukan penelitian dan pengabdian kepada masyarakat, terutama bagi pendidik pada perguruan tinggi.

Pendidikan secara profesional melaksanakan pendidikan di lernbaga pendidikan formal (sekolah) dan non formal (pendidikan luar sekolah). Sekolah sebagai wadah atau lembaga pendidikan formal mempunyai tugas berat dalam menghasilkan lulusan-lulusan yang sesuai dengan kualifikasi yang diharapkan, karena dalam melaksanakan proses pendidikan di sekolah diperlukan seperangkat komponen yang merupakan suatu sistem yang terdiri dari subsistemsubsistem seperti siswa, kurikulum, 
guru, Kepala Sekolah, laboran, pustakawan, buku pelajaran, alat bantu, gedung sekolah, pedoman pengelolaan sekolah, pembinaan dan evaluasi. Keseluruhan hal tersebut perlu dikelola guru dengan sebaik-baiknya.

Untuk meningkatkan kualitas pendidikan, pemerintah dan lembaga-lembaga yang bergerak dalam bidang pendidikan telah melakukan berbagai pembaharuan dan penyempurnaan. Dalam usaha mencapai kualitas hasil pendidikan yang optimal, aspek-aspek yang ada kaitannya dengan proses belajar mengajar perlu dievaluasi dan disempurnakan, rnisalnya aspek kurikulum, kualitas guru dan metode pembelajaran.

Untuk menanggulangi rendahnya kualitas sumber daya tenaga pendidikan pada setiap jenjang pendidikan, khususnya di Madrasah Tsanawiyah perlu dilakukan perbaikan atau peningkatan pada faktor-faktor yang diduga mempengaruhi kompetensi guru. Hal ini terus berdampak secara nasional, di mana keadaan pendidikan Indonesia semakin rendah dibandingkan dengan keadaan pendidikan di negara lainnva.

Salah satu faktor utama dalam pelaksanaan pendidikan di Madrasah Tsanawiyah adalah faktor tenaga pengajar. Rendahnya kualitas tenaga pengajar akan berpengaruh pada kemampuan dan keberhasllan melaksanakan tugas atau dengan kata lain tidak dapat melaksanakan tugas secara baik dan tepat. Kompetensi guru merupakan gambaran keberhasilan guru melaksanakan tugas, baik sebagai tenaga pengajar maupun pendidik. Tinggi rendahnya kompetensi guru sangat ditentukan seberapa besarnya motivasi guru ingin menyelesaikan pekerjaan untuk meraih prestasi, dan kebiasaan belajarnya, serta media pembelajaran yang digunakannya, sehingga dapat melaksanakan tugas dengan baik, tepat waktu, serta memenuhi kualitas standar kerja.

Untuk mernperoleh gambaran yang lebih tentang hasil penelitian ini, maka penulis akan memfokuskan penelitiannya kepada guru pasca diklat guru IPA Madrasah Tsanawiyah Se Sumatera Utara. Hal ini mengingat IPA merupakan salah satu bidang studi yang diujikan dalam ujian nasional, serta termasuk mata pelajaran yang sulit dipelajari oleh siswa, tetapi ia mempunyai peran yang sangat penting dalam menunjang keberhasilan belajar siswa. Oleh sebab itu sangatlah penting untuk diteliti secara lebih mendalam tentang kompetensi guru IPA tersebut, sehingga dapat diketahui permasalahannya secara lebih rinci, serta beberapa usaha untuk peningkatan, khususnya melalui motivasi berprestasi, kebiasaan belajar, dan penggunaan media 
pembelajaran.

Tujuan penelitian ini adalah untuk rnengetahui hubungan antara motivasi berprestasi, kebiasaan belajar, dan penggunaan media pembelajaran secara bersama-sama dengan kinerja guru IPA Madrasah Tsanawiyah pasca diklat.

\section{Hakikat Kompetensi Guru}

Soetjipto dan Kosasi (2000:37) menyatakan bahwa jabatan guru merupakan jabatan profesional, dan sebagai jabatan profesional, pemegangnya harus memenuhi kualifikasi tertentu. Kriteria jabatan profesional antara lain bahwa jabatan itu melibatkan kegiatan intelektual, mempunyai batang tubuh ilmu yang khusus, memerlukan persiapan lama untuk memangkunya, memerlukan latihan dalam jabatan yang bersinambungan, merupakan karier hidup dan keanggotaan yang permanen, menentukan baku perilakunya, mementingkan layanan, mempunyai organisasi profesional, dan mempunyai kode etik yang ditaati oleh anggotanya. Dengan adanya profesionalitas ini, maka guru akan melaksanakan tugasnya dengan baik.

Kompetensi Guru merupakan seperangkat pengetahuan, keterampilan, dan perilaku yang harus dimiliki, dihayati, dikuasai, dan diwujudkan oleh guru dalam melaksanakan tugas keprofesionalannya. Ditampilkan melalui unjuk kerja. Kepmendiknas No.045/U/2002 menyebutkan kompetensi sebagai seperangkat tindakan cerdas dan penuh tanggung jawab dalam melaksanakan tugas sebagai agen pembelajaran. Menurut Undangundang Guru dan Dosen No. 14/2005 dan Peraturan Pemerintah No.19/2005 dinyatakan bahwa 4 kompetensi yang harus dimiliki oleh guru yaitu: (a) Kompetensi profesional, (b) Kompetensi kepribadian, (c) Kompetensi pedagogik dan (d) Kompetensi sosial.

Sejalan dengan hal di atas, menurut Aqib (2002:47) bahwa untuk mewujudkan kompetensi guru yang profesional, secara ideal ada beberapa karakteristik citra guru yang diharapkan, antara lain : (1) Guru yang memiliki semangat juang yang tinggi disertai dengan kualitas keimanan dan ketaqwaan yang mantap (2) Guru yang mampu mewujudkan dirinya dalam keterkaitan dan padanan dengan tuntutan lingkungan dan perkembangan IPTEK (3) Guru mempunyai kualitas kompetensi pribadi dan professional yang memadai disertai atas kerja yang kuat (4) Guru yang memiliki kualitas kesejahteraan yang memadai (5) Guru yang mandiri, kreatif, dan berwawasan masa depan. 


\section{Hakikat Motivasi Berprestasi}

Atkitson, dkk (1993: 14) mengatakan motivasi adalah membicarakan faktor-faktor yang memberi energi dan arah pada prilaku manusia. Selain dari pengertian motivasi ini, masih banyak lagi pengertian motivasi lain yang dikemukakan oleh para ahli dengan titik tekan yang berbeda sesuai dengan sudut pandang masing-rnasing setiap ahli. Siagian (1989: 138), menganggap motivasi sebagai daya pendorong yang mengakibatkan seorang mau dan rela menggerakkan semua kemampuan, tenaga, dan waktunya untuk menyelenggarakan berbagai bentuk kegiatan yang menjadi tangungjawabnya yang wajib dikerjakan dalam rangka pencapaian tujuan serta berbagai sasaran organisasi yang telah ditentukan sebelumnya.

Teori motivasi kebutuhan dikemukakan oleh Maslow (1994: 39-51), yattu (1) psitsycological need atau kebutuhan fisik sebagai kebutuhan terendah manusia harus dipenuhi agar seseorang dapat bertahan hidup, mencakup: rnakanan, air, seks, dan tidur, (2) safety and security need atau kebutuhan keselamatan, mencakup ke-amanan dan stabilitas, dan perlindungan, (3) belongingness, social and love needofau kebutuhan sosial, mencakup: cinta, kasih, sayang, dan kerja sama antar sesarna orang lain, (4) estem need atau kebutuhan penghargaan yang mencakup penghargaan terhadap diri, priestise dan status, (5) self actualizaton need atau kebutuhan akan pewujudan diri mencakup: kreativitas, melaksanakan salah satu kemampuan yang dimiliki. Hirarki kebutuhan dan teori Maslow dapat dilihat dari Gambar di bawah ini:

Dari uraian di atas, dapat disimpulkan bahwa ada tiga jenis unsur utama dari motivasi berprestasi, yaitu: kebutuhan yang merangsang, tingkah laku yang diarahkan pada pencapaian tujuan, dan tujuan yang akan dicapai. Ketiga komponen utama dalam motivasi berprestasi tersebut antara satu sama lain berhubungan erat. Unsur utama dan pertama kebutuhan mempengaruhi unsur tingkah laku unsur kedua (tingkah laku diarahkan pada pencapaian tujuan) mempengaruhi dan mendorong terwujudnya tujuan yang akan dicapai. Sedangkan unsur ketiga (tujuan yang ingin dicapai) turut mempengaruhi unsur kebutuhan dan unsur tingkah laku rnariusia dan seterusnya.

\section{Hakikat Kebiasaan Belajar}

Menurut Surakhmad (1994: 5), belajar merupakan suatu proses yang terjadi dalam diri manusia. Proses tersebut tersebut menghasilkan perubahan tingkah laku dan kemampuan. Belajar juga 
dapat diartikan pendayagunaan waktu, dana, mental, energi dan fisik untuk menyerap bahan informasi dari berbagai sumber. Keberhasilan pencapaian belajar seseorang sangat dipengaruhi oleh kebiasaan belajar yang dilakukan.

Menurut Harjana (1994: 54), Kebiasaan belajar merupakan kemudahan yang dimiliki seseorang dalam melaksanakan tugas belajar. Orang yang memiliki Kebiasaan belajar dapat mulai tepat waktu belajar pada waktu yang telah ditentukan, serta mendapatkan hasil yang maksimal sesuai dengan kemampuan. Satu hal yang penting dalam membentuk Kebiasaan belajar yang baik adalah dengan menentukan jadwal belajar, karena dengan jadwal belajar dapat diketahui bahan apa yang akan dipelajari dan berapa lama bahan tersebut akan dipelajari dan dikerjakan. Berdasarkan uraian tersebut, maka Kebiasaan belajar yang baik adalah belajar menurut waktuyang ditentukan sebelumnya, kemudian melakukan kegiatan berupa membaca, mencatat, meringkas dan sebagainya.

\section{Hakikat Penggunaan Media Pembelajaran}

Dilihat dari segi etimologi, kata "media" berasal dari bahasa Latin dan merupakan jamak dari kata medium Gagne (1970:63) menyatakan bahwa media adalah berbagai jenis komponen dalam lingkungan siswa yang dapat merangsangnya untuk belajar. Sementara itu Brigss (1970:42) berpendapat bahwa media adalah segala alat fisik yang dapat menyajikan pesan serta merangsang siswa untuk belajar, seperti buku, film, kaset, dan sebagainya.

Sardinian, dkk., (2003:6) menyatakan bahwa media pada mulanya hanya dianggap sebagai alat bantu mengajar (Teaching Aids) dengan masuknya pengaruh teknologi audio pada sekitar pertengahan abad ke 20, alat visual untuk mengkongkritkan pembelajaran ini dilengkapi dengan audio, sehingga dikenal alat audio visual atau audio visual aids (AVA).

Fungsi media dalam hubungan dengan proses belajar mengajar antara lain dinyatakan Shalahuddtn (1986: 18-19); yaitu: (1). Media memungkinkan siswa menyaksikan benda/peristiwa yang ada terjadi pada masa lampau secara nyata. (2). Media memungkinkan siswa mengamati benda/peristiwa yang sukar dikunjungi, baik karena tempatnya jauh, karena tempatnya berbahaya, atau karena terlarang. (3). Media memungkinkan siswa untuk memperoleh gambaran yang jelas tentang benda/ masalah yang sukar diamati secara langsung karena ukurannya yang terlalu besar atau terlalu kecil. (4). 
Media memungkinkan kegiatan belajar diikuti oleh banyak siswa/ mahasiswa, seperti melalui radio atau 'IV. (5)). Media dapat memperlihatkan secara cepat suatu proses yang berlangsung secara lambat, misalnya proses perkcmbangan kejadian manusia mulai dari sperma sampai menjadi janin, hanya ditunjukkan dalam beberapa menit. (6). Media dapat memperlihatkan secara lambat gerakan-gerakan yang amat cepat, jika diperlukan untuk diamati secara teliti.

Dari uraian di atas dapat disimpulkan bahwa media pengajaran merupakan komponen pengajaran yang sangat penting dalam proses belajar mengajar. la membantu meningkatkan kegiatan belajar siswa, yang pada akhirnya akan dapat meningkatkan hasil belajar yang lebih baik pada diri siswa.

Hasil penelitian yang relevan tentang media pembelajaran adalah yang dilakukan oleh Gene $L$. Wilkinson (1980) yang menyatakan bahwa penggunaan media pembelajaran telah memberikan kontribusi yang sangat positif terhadap usaha pengkonkritkan bahan pembelajaran, dan sekaligus memberikan efek memudahkan terhadap pemahaman siswa mengenaibahanyang dipelajarinya.
Penelitian yang relevan tentang kompetensi guru antara lain hasil penelitian Budi Suhartono (2003) yang menyatakan motivasi berprestasi memberikan konstribusi yang signifikan terhadap kinerja guru Bimbingan Konseling di Madrasah Tsanawiyah Kota Medan.

\section{METODE PENELITIAN}

Metode penelitian yang digunakan adalah metode survey, dengan teknik analisis korelasional. Metode survey digunakan untuk mengumpulkan data dari sejumlah guru dalam jangka waktu yang relatif bersamaan.

Penelitian ini dilaksanakan di Madrasah Tsanawiyah Se Sumatera Utara pada bulan Juli sampai dengan Agustus 2017. Populasi dalam penelitian ini adalah seluruh guru IPA Madrasah Tsanawiyah Se Sumatera Utara, tahun 2017 yang berjumlah 40 orang. Teknik pengambilan sampel dalam penelitian ini dilakukan melalui pengambilan sampel secara acak (simple random sampling). Jumlah sampel dalam penelitian ini ditentukan sebanyak 40 orang guru atau $100 \%$ dari jumlah populasi. Penilaian dilakukan dengan menggunakan instrumen angket berskala likert. 


\section{TEMUAN DAN PEMBAHASAN}

\section{Temuan}

\section{a. Data Motivasi Berprestasi}

Hasil skor penelitian motivasi berprestasi $\left(X_{1}\right)$ dapat dilihat pada Lampiran 4. Skor tertinggi 79 dan terendah 48. Nilai ratarata $x=61,92$ standar deviasi $s=7,29$, variansi $s^{2}=53,17$, median $\mathrm{Me}=60,59$, serta Modus Mo $=61,28$, (Lampiran 6). Untuk lebih jelasnya sebaran data motivasi berprestasi guru IPA Madrasah Tsanawiyah Se Sumatera Utara dapat dilihat pada Daftar distribusi frekuensi skor motivasi berprestasi guru IPA Madrasah Tsanawiyah Se Sumatera Utara seperti Tabel 1, di bawah ini:

Tabel 1. Daftar Distribusi Frekuensi Skor Motivasi Berprestasi Guru IPA di Madrasah Tsanawiyah

\begin{tabular}{|c|c|c|c|}
\hline No Kelas & Interval Kelas & Frekuensi & Persentase \\
\hline 1 & $48-53$ & 4 & $10 \%$ \\
\hline 2 & $54-59$ & 12 & $30 \%$ \\
\hline 3 & $60-65$ & 14 & $35 \%$ \\
\hline 4 & $66-71$ & 5 & $13 \%$ \\
\hline 5 & $72-77$ & 4 & $10 \%$ \\
\hline 6 & $78-83$ & 1 & $3 \%$ \\
\hline \multicolumn{2}{|l|}{ Jumlah } & 40 & $100 \%$ \\
\hline
\end{tabular}

Dari tabel distribusi frekuensi di atas maka dapat dijelaskan bahwa kelas interval pertama dengan skor 48-53 terdapat 4 orang guru (10\%), kelas interval kedua skor 54-59 terdapat 12 orang guru (30\%), kelas interval ketiga dengan skor $60-65$ terdapat 14 orang guru (35\%), kelas interval keempat dengan skor 66-71 terdapat 5 orang guru (13\%), kelas interval kelima dengan skor $72-77$ terdapat 4 orang guru $(10 \%)$ dan kelas interval keenam 78-83 terdapat 1 orang guru (3\%).

Jika ditinjau kecenderungan motivasi berprestasi berdasarkan patokan yang ditetapkan yaitu baik bila dapat menguasai $\geq 80 \%$, sedang bila dapat menguasai tes $\geq 60 \%$ $79 \%$, dan kurang bila mengusai $\leq 60 \%$. Kategori motivasi berprestasi guru IPA Madrasah Tsanawiyah diuraikan tabel 8 berikut ini: 
Tabel 2. Kategori Motivasi Berprestasi

\begin{tabular}{|l|l|c|c|}
\hline No & Kegori & Jumlah & Persetase \\
\hline 1 & Baik & 11 & $27,5 \%$ \\
\hline 2 & Sedang & 29 & $72,5 \%$ \\
\hline 3 & Kurang Jumlah & 0 & $0 \%$ \\
\hline \multicolumn{2}{|c|}{} & 40 & $100,0 \%$ \\
\hline
\end{tabular}

Dari tabel 2 di atas, dapat dijelaskan bahwa sebanyak 11 orang guru kimia (27,5\%) memiliki kecenderungan motivasi berprestasi baik, 29 orang (72,5\%) memiliki kecendrungan motivasi berprestasi baik, 29 orang (72,5\%) memiliki kualitas motivasi berprestasi sedang dan tidak ada guru yang memiliki motivasi berprestasi rendah.

\section{b. Data Kebiasaan Belajar}

Hasil skor penelitian kebiasaan belajar $\left(X_{2}\right)$ dapat dilihat pada lampiran 4 skor tertinggi 100 dan terendah 54. Nilai ratarata $x=77,10$, standar deviasi $s=11,16$, varians $s^{2}=1245,55$, median $\mathrm{Me}=78,14$, serta Modus Mo $=81,00$ (lampiran 6). Untuk lebih jelasnya sebaran data kebiasaan belajar guru IPA Madrasah Tsanawiyah Se Sumatera Utara dapat dilihat seperti tabel 3 di bawah ini.

Tabel 3. Daftar Distribusi Frekuensi Skor Kebiasaan Belajar Guru IPA Madrasah Tsanawiyah Se Sumatera Utara

\begin{tabular}{|c|c|c|c|}
\hline No Kelas & Interval Kelas & Frekuensi & Persentase \\
\hline 1 & $54-61$ & 4 & $10 \%$ \\
\hline 2 & $62-69$ & 7 & $18 \%$ \\
\hline 3 & $70-77$ & 8 & $20 \%$ \\
\hline 4 & $78-85$ & 11 & $28 \%$ \\
\hline 5 & $86-93$ & 8 & $20 \%$ \\
\hline 6 & $94-101$ & 2 & $5 \%$ \\
\hline \multicolumn{2}{|l|}{ Jumlah } & 40 & $100 \%$ \\
\hline
\end{tabular}

Dari tabel distribusi frekuensi di atas maka dapat dijelaskan bahwa kelas interval pertama dengan skor 54-61 terdapat 4 orang guru (10\%), kelas interval kedua skor 62-69 terdapat 7 orang guru (18\%), kelas interval ketiga dengan skor 70-71 terdapat 8 orang guru (20\%), kelas interval keempat dengan skor 7885 terdapat 11 orang guru (28\%), 
kelas interval kelima dengan skor $86-93$ terdapat 8 orang guru (20\%) dan kelas interval keenam 94-101 terdapat 2 orang guru (5\%).

Jika ditinjau kecenderungan kebiasaan belajar berdasarkan patokan yang ditetapkan yaitu baik bila dapat menguasai tes $\geq$
$80 \%$, sedang bila dapat menguasai tes $\geq 60 \%-79 \%$, dan kurang bila mengusai $\leq 60 \%$ - 79\%, dan kurang bila mengusai $\leq 60 \%$. Kategori kebiasaan belajar guru IPA Madrasah Tsanawiyah Se Sumatera Utara diuraikan pada Tabel 4 berikut ini:

Tabel 4. Kategori kebiasaan belajar guru Kimia Madrasah Aliyah Se Sumatera Utara

\begin{tabular}{|c|l|c|c|}
\hline No & Kegori & Jumlah & Persetase \\
\hline 1 & Baik & 6 & $15,0 \%$ \\
\hline 2 & Sedang & 26 & $72,5 \%$ \\
\hline 3 & Kurang Jumlah & 5 & $12,5 \%$ \\
\hline \multicolumn{2}{|c|}{} & 40 & $100,0 \%$ \\
\hline
\end{tabular}

Dari tabel 10 di atas, dapat dijelaskan bahwa sebanyak 6 orang guru kimia $(15,0 \%)$ memiliki kecenderungan kebiasaan belajar baik, 29 orang $(72,5 \%)$ memiliki kualitas kebiasaan belajar sedang dan sebanyak 5 orang guru $(12,5 \%)$ memiliki kebiasaan belajar yang kurang.

\section{c. Data Penggunaan Media Pembelajaraan}

Hasil skor Penggunaan Media Pembelajaran $\left(\mathrm{X}_{3}\right)$ dapat dilihat pada lampiran 4. Skor tertinggi 100 dan terendah 54 . Nilai ratarata $x=78,65$, standar deviasi $\mathrm{s}=$ 12,32 , variansi $\mathrm{s}^{2}=151,82$, median $\mathrm{Me}=78,00$, serta Modus Mo = 80,00, (Lampiran 6). Untuk lebih jelasnya sebaran data Penggunaan Media Pembelajaran oleh guru IPA Madrasah Tsanawiyah Se Sumatera Utara dapat dilihat pada Daftar distribusi frekuensi skor Penggunaan Media Pembelajaran guru IPA Madrasah Tsanawiyah Se Sumatera Utara seperti tabel 5 di bawah ini.

Tabel 5. Daftar Distribusi Frekuensi Skor Penggunaan Media Pembelajaran Guru IPA Madrasah Tsanawiyah Se Sumatera Utara

\begin{tabular}{|c|c|c|c|}
\hline No Kelas & Interval Kelas & Frekuensi & Persentase \\
\hline 1 & $49-57$ & 2 & $5 \%$ \\
\hline 2 & $68-66$ & 5 & $13 \%$ \\
\hline
\end{tabular}




\begin{tabular}{|c|c|c|c|}
\hline 3 & $67-75$ & 8 & $20 \%$ \\
\hline 4 & $76-84$ & 12 & $30 \%$ \\
\hline 5 & $85-93$ & 8 & $20 \%$ \\
\hline 6 & $94-102$ & 5 & $13 \%$ \\
\hline \multicolumn{2}{|c|}{ Jumlah } & 40 & $100 \%$ \\
\hline
\end{tabular}

Dari tabel distribusi frekuensi di atas maka dapat dijelaskan bahwa kelas interval pertama dengan skor 59-57 terdapat 2 orang guru (5\%), kelas interval kedua skor 58-66 terdapat 5 orang guru (13\%), kelas interval ketiga dengan skor 67-75 terdapat 8 orang guru (20\%), kelas interval keempat dengan skor 7684 terdapat 12 orang guru (30\%), kelas interval kelima dengan skor $85-93$ terdapat 8 orang guru (20\%) dan kelas interval keenam 94-102 terdapat 5 orang guru (13\%).

Kualitas penggunaan media pembelajaran berdasarkan patokan yang ditetapkan yaitu baik bila dapat menguasai tes $\geq 80 \%$, sedang bila dapat menguasai tes $\geq 60 \%$ $79 \%$, dan kurang bila menguasai $\leq$ $60 \%$. Kategori penggunaan media pembelajaran diuraikan pada tabel 6 berikut:

Tabel 6. Histogram skor penggunaan media pembelajaran

\begin{tabular}{|l|l|c|c|}
\hline No & \multicolumn{1}{|c|}{ Kegori } & Jumlah & Persetase \\
\hline 1 & Baik & 5 & $12,5 \%$ \\
\hline 2 & Sedang & 28 & $70,0 \%$ \\
\hline 3 & Kurang Jumlah & 7 & $17,5 \%$ \\
\hline \multicolumn{2}{|c|}{ Jum } & $100,0 \%$ \\
\hline
\end{tabular}

Dari tabel 6 di atas, dapat dijelaskan bahwa sebanyak 5 orang guru kimia $(12,5 \%)$ memiliki kecenderungan penggunaan media pembelajaran baik, 28 orang (70\%) memiliki kecendrungan penggunaan media pembelajaran sedang dan sebanyak 7 orang guru $(17,5 \%)$ memiliki kecenderungan penggunaan kebiasaan pembelajaran yang kurang.

\section{d. Data Kompetensi Guru IPA}

Hasil skor kompetensi guru (Y) dapat dilihat pada lampiran 4. Skor tertinggi 60 dan terendah 49. Nilai rata-rata $x=53,15$, standar deviasi $\mathrm{s}=2,56$ varians $\mathrm{s}^{2}$ =6,54, median $\mathrm{Me}=52,95$, serta modus Mo $=52,93$, (Lampiran 6). Untuk lebih jelasnya sebaran data kompetensi guru IPA Madrasah Tsanawiyah dapat dilihat pada daftar distribusi frekuensi skor 
kompetensi guru IPA Madrasah Tsanawiyah Se Sumatera Utara seperti tabel 7

Tabel 7. Daftar Distribusi Frekuensi Skor kompetensi Guru IPA Madrasah Tsanawiyah Se Sumatera Utara

\begin{tabular}{|c|c|c|c|}
\hline No Kelas & Interval Kelas & Frekuensi & Persentase \\
\hline 1 & $49-50$ & 5 & $13 \%$ \\
\hline 2 & $51-52$ & 12 & $30 \%$ \\
\hline 3 & $53-54$ & 15 & $38 \%$ \\
\hline 4 & $55-56$ & 3 & $8 \%$ \\
\hline 5 & $57-58$ & 3 & $8 \%$ \\
\hline 6 & $59-60$ & 2 & $5 \%$ \\
\hline \multicolumn{2}{|c|}{ Jumlah } & 40 & $100 \%$ \\
\hline
\end{tabular}

Dari tabel distribusi frekuensi di atas maka dapat dijelaskan bahwa kelas interval pertama dengan skor 49-50 terdapat 5 orang guru (13\%), kelas interval kedua skor $51-52$ terdapat 12 orang guru (30\%), kelas interval ketiga dengan skor 5354 terdapat 15 orang guru (38\%), kelas interval keempat dengan skor 55-56 terdapat 3 orang guru (8\%), kelas interval kelima dengan skor 57-58 terdapat 3 orang guru (8\%) dan kelas interval keenam 59-60 terdapat 2 orang guru (5\%).

Kualitas kompetensi kerja guru IPA berdasarkan patokan yang ditetapkan yaitu baik dapat menguasai tes $\geq 80 \%$, sedangkan bila dapat menguasai tes $\geq 60 \%$ $79 \%$, dan kurang bila menguasai $\leq 60 \%$. Kategori kinerja kerja guru IPA diuraikan pada tabel 8 berikut:

Tabel 8. Kategori kinerja guru Kimia

\begin{tabular}{|l|l|c|c|}
\hline No & \multicolumn{1}{|c|}{ Kegori } & Jumlah & Persetase \\
\hline 1 & Baik & 4 & $10,0 \%$ \\
\hline 2 & Sedang & 36 & $90,0 \%$ \\
\hline 3 & Kurang Jumlah & 0 & $0,0 \%$ \\
\hline \multicolumn{2}{|c|}{} & 40 & $100,0 \%$ \\
\hline
\end{tabular}

Dari tabel 8 di atas, dapat dijelaskan bahwa sebanyak 4 orang guru kimia (10\%) memiliki kecenderungan kompetensi baik, 36 orang (90\%) memiliki kecendrungan kompetensi sedang dan tidak ada guru yang memiliki kecenderungan kompetensi yang rendah. 


\section{Uji Persyaratan Analisis Data}

Pengujian persyaratan analisis data dalam penelitian ini difokuskan pada uji normalitas data dan uji linieritas regresi.

\section{Pengujian Normalitas Data}

Pengujian normalitas data untuk masing-masing data penelitian digunakan uji Normalitas galat taksiran. Untuk menarik kesimpulan apakah galat taksiran $y$ atas variabel-variabel $X_{1}, X_{2}$ dan $\mathrm{X}_{3}$ berdistribusi normal atau tidak dilakukan dengan uji Lillieofors. Hasil perhitungan dari harga $L_{\text {hitung }}$ kemudian dicarai harga tertinggi yang kemudian disebut dengan Lo. Selanjutnya Lo ini dikonsultasikan dengan $\mathrm{L}_{\text {tabel }}$ dengan $\mathrm{dk}=\mathrm{n}$ pada taraf signifikain $\alpha=0,05$. Suatu galat taksiran $y$ atas variabelvariabel $X_{1}, X_{2}$ dan $X_{3}$ berdistribusi normal jika Lo $<\mathrm{L}_{\text {tabel. }}$. Sebaliknya, jika harga tersebut tidak terpenuhi maka galat taksiran $y$ atas variabelvariabel $X_{1^{\prime}} X_{2}$ dan $X_{3}$ berdistribusi normal.

Rangkuman hasil pengujian normalitas galat taksiran $y$ atas variabel-variabel $X_{1^{\prime}} \quad X_{2}$ dan $X_{3}$ berdistribusi normal dapat dilihat pada tabel 9 di bawah ini:

Tabel 9. Rangkuman Uji Normalitas

\begin{tabular}{|c|c|c|c|c|}
\hline Galat Taksiran $y$ atas & $\mathrm{dk}$ & Lo & $\mathrm{L}_{\text {tabel }(0,05)}$ & Keterangan \\
\hline $\mathrm{X}_{1}$ & 40 & 1,393 & 1,401 & Distribusi Normal \\
\hline $\mathrm{X}_{2}$ & 40 & 1,394 & 1,401 & Distribusi Normal \\
\hline $\mathrm{X}_{3}$ & 40 & 1,369 & 1,401 & Distribusi Normal \\
\hline
\end{tabular}

Dari tabel 9 di atas dapat dijelaskan bahwa galat taksiran $y$ atas $X_{1}$ diperoleh Lo $=0,1393$ dalam im $\mathrm{dk}=40$ pada $\alpha=0,05$ $\mathrm{L}_{\text {tabel }}=0,1401$, sehingga $\mathrm{Lo}=0,1399$ $<L_{\text {tabel }}=0,1401$. Dengan demikian dapat disimpulkan bahwa galat taksiran $y$ atas $\mathrm{X}_{2}$ memiliki sebaran normal. Dan selanjutnya, untuk galat taksiran $y$ dan $\mathrm{X}_{3}$ diperoleh Lo $=0,1369$ dan untuk $\mathrm{dk}=40$ pada $\alpha=0,05 \mathrm{~L}_{\text {tabel }}=1.401$, sehingga Lo $=0,1371<\mathrm{L}_{\text {tabel }}=0,1401$. Dengan demikian dapat disimpulkan bahwa galat taksiran $y$ atau $X_{3}$ memiliki sebaran normal.

Sehingga sebagai kesimpulan secara umum, bahwa galat taksiran $Y$ atas variabel $\mathrm{X}_{1^{\prime}} \mathrm{X}_{2}$ dan $\mathrm{X}_{3}$ memiliki distribusi "normal".

\section{Pengujian Linieritas Regresi}

Untuk mengetahui apakah setiap variabel memiliki hubungan yang linier terhadap variabel terikat, maka digunakan uji 
linieritas. Teknik yang digunakan adalah teknik analisis regresi sederhana. Hubungan yang linier antara variebal dapat diketahui dari persamaan garis regresi yang dibentuk oleh setiap variabel.
Bila harga $F_{\text {hitung }}<\mathrm{F}_{\text {tabel }}$ pada tarafi signifikansi tertentu, maka hubungan antara kedua variabel adalah linier. Rangkuman hasil uji linieritas regresi dapat dilihat pada tabel 10 di bawah ini:

Tabel 10. Rangkuman Uji Linieritas Regresi

\begin{tabular}{|c|c|c|c|c|c|c|}
\hline \multirow{2}{*}{ Variabel } & \multicolumn{2}{|c|}{ Koefisien regresi } & \multicolumn{2}{c|}{ Regresi } & \multicolumn{2}{c|}{ Tuna Cocok } \\
\cline { 2 - 7 } & $\mathrm{a}$ & $\mathrm{B}$ & $\mathrm{Fh}$ & $\mathrm{Ft}$ & $\mathrm{Fh}$ & $\mathrm{Ft}$ \\
\hline $\mathrm{X}_{1}$ terhadap $\mathrm{Y}$ & 41,2 & 0,19 & 15,536 & 4,098 & 0,555 & 2,168 \\
\hline $\mathrm{X}_{2}$ terhadap $\mathrm{Y}$ & 44,31 & 0,11 & 13,5343 & 4,098 & 0,810 & 2,191 \\
\hline $\mathrm{X}_{3}$ terhadap $\mathrm{Y}$ & 44,80 & 0,11 & 11,68 & 4,098 & 0,34 & 2,191 \\
\hline
\end{tabular}

Dari tabel 10 di atas dapat dijelaskan bahwa untuk variabel $\mathrm{X}_{1}$ terhadap $\mathrm{Y}$ diperoleh $\mathrm{F}_{\text {hitung }}=$ 0,555 dan $F_{\text {tabel }}=2,166$ pada $\alpha=$ $0,555<\mathrm{F}_{\text {tabel }}=2,168 \mathrm{X}_{1}$ terhadap $\mathrm{Y}$ adalah linier. Untuk variabel $\mathrm{X}_{2}$ terhadap $Y$ diperoleh $\mathrm{F}_{\text {hitung }}=0,810$ dan $\mathrm{F}_{\text {tabel }}=2,191$ pada $\alpha=0,05$ dengan $d k=(20,18)$, sehingga jelas untuk variabel $X_{1}$ terhadap $Y_{1} F_{\text {hitung }}=0,810<F_{\text {tabel }}=2,191$. Dengan demikian hasil uji linieritas menyimpulkan bahwa model regresi variabel $X_{2}$ terhadap $Y$ adalah linier. Dan untuk variabel $X_{3}$ terhadap $Y$ diperoleh $F_{\text {hitung }}=0,340$ dan $F_{\text {tabel }}=2,191$ pada $\alpha=0,340$ $<\mathrm{F}_{\text {tabel }}=2$,109. Dengan demikian hasil uji linieritas menyimpulkan bahwa model regresi variabel $\mathrm{X}_{3}$ terhadap $Y$ adalah linier.

\section{Pengujian Hipotesis Penelitian}

Pengujian persyaratan analisis menunjukkan bahwa skor tiap variabel penelitian telah memenuhi persyaratan untuk pengujian statistik lebih lanjut. Berikut ini akan disajikan pengujian hipotesis penelitian.

\section{Hubungan Motivasi Berprestasi Dengan kompetensi Guru}

Hasil perhitungan analisis regresi sederhana untuk variabel motivasi berprestasi dengan kompetensi guru diperoleh persamaan garis regresi $Y=41,2+0,19 X_{1}$. Ringkasan hasil uji signifikan koefisien regresi dan linieritas dapat dilihat seperti pada tabel 11 di bawah ini: 
Tabel 11. Analisis Varians untuk pengujian signifikasi dan linieritas regresi $\hat{Y}=41,2+0,19 \mathrm{X}_{1}$

\begin{tabular}{|c|c|c|c|c|c|}
\hline Sumber Variasi & $\mathbf{d k}$ & JK & RJK & Fh & Ft: $_{\boldsymbol{\alpha}=\mathbf{0 . 0 5}}$ \\
\hline Total & 40 & 113268.00 & 113268.00 & - & - \\
\hline Regresi (a) & 1 & 112996.90 & 112996.90 & - & - \\
\hline Residu & 1 & 78.67 & 78.67 & 15.536 & 4.098 \\
\hline Residu & 38 & 192.429 & 5.06 & - & - \\
\hline Tuna Cocok & 19 & 68.68 & 3.61 & 0.555 & 2.168 \\
\hline Galat & 21 & 123.75 & 5.89 & - & - \\
\hline
\end{tabular}

Perhitungan keberartian regresi $Y$ atas $X_{1}$ pada tabel 11 di atas menunjukkan bahwa harga $F_{h}$ $>F_{t}$ ini berarti bahwa koefisien arah regresi $Y$ atas $X_{1}$ signifikan pada $\alpha=$ 0,05 . Dengan demikian persamaan regresi $\widehat{Y}=41,2+0,19 \mathrm{X}_{1}$ dapat dipertanggungjawabkan untuk menarik kesimpulan mengenai hubungan motivasi berprestasi dengan kompetensi guru kimia Madrasah Aliyah Se-Sumatera Utara. Dari persamaan ini dapat dijelaskan bahwa peningkatan satu skor motivasi berprestasi menyebabkan peningkatan sebesar 0,19 skor kompetensi guru pada konstansi 41,2.
Berdasarkan perhitungan korelasi variael $\mathrm{X}_{1}$ dengan $\mathrm{Y}$ diperoleh koefisien korelasi sebesar 0,539 dan harga $t=4,678$. Harga $\mathrm{t}_{\text {tabel }} \mathrm{dk}=38$ pada taraf signifikan $\alpha$ $=0,05$ diperoleh $t_{\text {tabel }}=2.02$. Oleh karena $t_{\text {hitung }}>t_{\text {tabel }}$ maka dapat disimpulkan bahwa hipotesis nol ditolak. Dengan demikian hipotesis penelitian yang diajukan "terdapat hubungan antara motivasi berprestasi dengan kompetensi guru" teruji sebenarnya.

Rangkuman hasil pengujian hipotesis penelitian ini dapat dilihat pada tabel 18 di bawah ini:

\begin{tabular}{|c|c|c|c|c|c|c|c|}
\hline Variabel & $\mathrm{n}$ & $\mathrm{R}$ & $\mathrm{r}^{2}$ & $\mathrm{dk}$ & $\mathrm{t}_{\text {hit }}$ & $\mathrm{T}_{\text {tabel }(0,0)}$ & $\mathrm{t}_{\text {tab(0,01) }}$ \\
\hline $\mathrm{X}_{1}$ terhadap $\mathrm{Y}$ & 40 & 0,538 & 0,29 & 38 & 4,678 & 2,02 & 2,71 \\
\hline
\end{tabular}

Koefisien determinasi adalah kuadrat dari koefisien korelasi antara $X_{1}$ dengan $Y$ yaitu sebesar 0,29 . Ini menunjukkan bahwa $29 \%$ variasi yang terjadi pada kompetensi guru dapat dijelaskan oleh motivasi berprestasi melalui persamaan garis regresi $\hat{Y}=41,2$ $+0,19 X_{1}$.

\section{Hubungan Kebiasaan Belajar dengan Kompetensi Guru}

Hasil perhitungan analisis regresi sederhana untuk variabel kebiasaan belajar dengan kompetensi guru diperoleh persamaan garis regresi $\bar{Y}=$ $44,31+0,11 \mathrm{X}_{2}$. Ringkasan hasil uji 
signifikan koefisien dan linieritas dapat dilihat seperti pada tabel $12 \mathrm{di}$ bawah ini:

Tabel 12. Analisis Varians untuk Pengujian Signifikasi dan Linieritas Regresi $\widehat{Y}=44,31+0,11 \mathrm{X}_{2}$

\begin{tabular}{|c|c|c|c|c|c|}
\hline Sumber Variasi & $\mathbf{d k}$ & JK & RJK & Fh & Ft: $_{\boldsymbol{\alpha}=\mathbf{0 . 0 5}}$ \\
\hline Total & 40 & 113268.00 & 113268.00 & - & - \\
\hline Regresi (a) & 1 & 112996.90 & 112996.90 & - & - \\
\hline Residu (b/a) & 1 & 70.45 & 70.45 & 13.343 & 4.098 \\
\hline Residu & 38 & 200.65 & 5.28 & - & - \\
\hline Tuna Cocok & 20 & 95.06 & 4.75 & 0.810 & 2.191 \\
\hline Galat & 18 & 105.58 & 5.87 & - & - \\
\hline
\end{tabular}

Perhitungan keberartian regresi $Y$ atas $X_{2}$ pada tabel 12 di atas menunjukkan bahwa harga $F_{h}$ $>F_{t}$ ini berarti bahwa koefisien arah regresi $Y$ atas $X_{1}$ signifikan pada $\alpha=$ 0,05 . Dengan demikian persamaan regresi $\widehat{Y}=44,31+0,11 \mathrm{X}_{2}$ dapat dipertanggungjawabkan untuk menarik kesimpulan mengenai hubungan motivasi berprestasi dengan kompetensi guru Madrasah Aliyah Se-Sumatera Utara. Dari persamaan ini dapat dijelaskan bahwa peningkatan satu skor motivasi berprestasi menyebabkan peningkatan sebesar 0,11 skor kompetensi guru pada konstansi 44,31 .
Berdasarkan perhitungan korelasi variabel $X_{2}$ dengan $Y$ diperoleh koefisien korelasi sebesar 0,509 dan harga $t=3,413$. Harga $t_{\text {tabel }}$ dengan $\quad \mathrm{dk}=$ 38 pada taraf signifikansi $\alpha=0,05$ diperoleh $t_{\text {tabel }} 2,02$. Oleh karena $t_{\text {hitung }}>t_{\text {tabel }}$ maka dapat disimpulkan bahwa hipotesis nol ditolak. Dengan demikian hipotesis penelitian yang diajukan "terdapat hubungan antara kebiasaan belajar dengan kompetensi guru" teruji kebenarannya.

Rangkuman hasil pengujian hipotesis penelitian ini dapat dilihat pada tabel 13 di bawah ini:

Tabel 13. Rangkuman hubungan antara kebiasaan belajar dengan kompetensi guru

\begin{tabular}{|c|c|c|c|c|c|c|c|}
\hline Variabel & $\mathrm{n}$ & $\mathrm{r}$ & $\mathrm{r}^{2}$ & $\mathrm{dk}$ & $\mathrm{t}_{\text {hit }}$ & $\mathrm{T}_{\text {tabel }(0,05)}$ & $\mathrm{t}_{\text {tab }(0,01)}$ \\
\hline $\mathrm{X}_{2}$ terhadap $\mathrm{Y}$ & 40 & 0,509 & 0,26 & 38 & 3,413 & 2,02 & 2,71 \\
\hline
\end{tabular}


Koefisien determinasi adalah kuadrat dari koefisien korelasi antara $\mathrm{X}_{1}$ dengan $\mathrm{Y}$ yaitu sebesar 0,26 . Ini menunjukkan bahwa $26 \%$ variasi yang terjadi pada kompetensi guru dapat dijelaskan oleh motivasi berprestasi melalui persamaan garis regresi $\hat{Y}=44,31$ $+0,11 X_{2}$.

\section{Hubungan Penggunaan Media Pembelajaran dengan Kompetensi Guru}

Hasil perhitungan analisis regresi sederhana untuk variabel Penggunaan Media Pembelajaran dengan kompetensi guru diperoleh persamaan garis regresi $\quad \hat{Y}=$ $44,80+0,11 X_{3}$. Ringkasan hasil uji signifikan koefisien dan linieritas dapat dilihat seperti pada tabel 14 di bawah ini:

Perhitungan keberartian regresi $Y$ atas $X_{3}$ pada tabel 21 menunjukkan bahwa harga $F_{h}>$ $F_{t}$ Ini berarti bahwa koefisien arah regresi $Y$ atas $X_{2}$ signifikan pada $\alpha=$ 0,05 . Dengan demikian persamaan regresi $\widehat{Y}=44,31+0,11 \mathrm{X}_{2}$ dapat dipertanggungjawabkan untuk menarik kesimpulan mengenai hubungan penggunaan media pembelajaran dengan kompetensi guru Madrasah Aliyah Se Sumatera Utara. Dari persamaan ini dapat dijelaskan bahwa peningkatan satu skor motivasi berprestasi menyebabkan peningkatan sebesar 0,11 skor kompetensi guru pada konstansi 44,3801.

Tabel 14. Analisis Varians untuk pengujian signifikasi dan linieritas regresi $\hat{Y}=44,80+0,11 \mathrm{X}_{3}$

\begin{tabular}{|c|c|c|c|c|c|}
\hline Sumber Variasi & $\mathbf{d k}$ & $\mathbf{J K}$ & $\mathbf{R J K}$ & $\mathbf{F h}$ & Ft: $_{\boldsymbol{\alpha}=\mathbf{0 . 0 5}}$ \\
\hline Total & 40 & 113268.00 & 113268.00 & - & - \\
\hline Regresi (a) & 1 & 112996.90 & 112996.90 & - & - \\
\hline Residu (b/a) & 1 & 63.75 & 63.75 & 11.68 & 4.10 \\
\hline Residu & 38 & 207.353 & 5.46 & - & - \\
\hline Tuna Cocok & 20 & 56.99 & 2.85 & 0.34 & 2.191 \\
\hline Galat & 18 & 150.37 & 8.35 & - & - \\
\hline
\end{tabular}

Berdasarkan perhitungan korelasi variabel $\mathrm{X}_{3}$ dengan $\mathrm{Y}$ diperoleh koefisien korelasi sebesar 0,485 dan harga $t=2,989$. Harga $t_{\text {tabel }} \mathrm{dk}=38$ pada taraf signifikan $\alpha=0,05$ diperoleh $t_{\text {tabel }}$ $=2,02$. Oleh karena $t_{\text {hitung }}>t_{\text {tabel }}$ maka dapat disimpulkan bahwa hipotesis nol ditolak. Dengan demikian hipotesis penelitian yang "terdapat hubungan antara penggunaan media pembelajaran dengan kompetensi guru" teruji kebenarannya. 
Rangkuman hasil pengujian hipotesis penelitian ini dapat dilihat pada tabel 15 di bawah ini:

Tabel 15. Rangkuman hubungan antara penggunaan media pembelajaran dengan kompetensi guru

\begin{tabular}{|c|c|c|c|c|c|c|c|}
\hline Variabel & $\mathrm{n}$ & $\mathrm{R}$ & $\mathrm{r}^{2}$ & $\mathrm{Dk}$ & $\mathrm{t}_{\text {hit }}$ & $\mathrm{t}_{\text {tabel }(0,05)}$ & $\mathrm{t} \mathrm{tab}_{(0,01)}$ \\
\hline $\mathrm{X}_{3}$ terhadap $\mathrm{Y}$ & 40 & 0,485 & 0,24 & 38 & 3,413 & 2,02 & 2,71 \\
\hline
\end{tabular}

Koefisien determinasi adalah kuadrat dari koefisien korelasi antara $Y_{3}$ dengan $Y$ yaitu sebesar 0,24 . Ini menunjukkan bahwa $24 \%$ variasi yang terjadi pada kompetensi guru dapat dijelaskan oleh kebiasaan belajar melalui persamaan garis regresi $\hat{Y}=44,80$ $+0,11 X_{3}$
4. Hubungan antara motivasi berprestasi, kebiasaan belajar, penggunaan media pembelajaran bersama-sama kompetensi guru secara dengan

Dari perhitungan analisis regresi linier ganda diperoleh persamaan garis regresi $\hat{Y}=36,36$ $+0,160 X_{1}+0,003 X_{2}+0,082 X_{3}$. Berikut disajikan tabel 23 tentang analisis variansi untuk regresi linier ganda.

Tabel 15. Analisis Varians untuk Regresi Linier Ganda untuk Persamaan regresi $\hat{Y}=36,36+0,160 \mathrm{X}_{1}+0,003 \mathrm{X}_{2}+0,082 \mathrm{X}_{3}$

\begin{tabular}{|c|c|c|c|c|c|c|}
\hline Sumber Variasi & $\mathbf{d k}$ & JK & RJK & Fhit & $\mathbf{F}_{\text {tab }(\boldsymbol{\alpha}=\mathbf{0 . 0 5})}$ & $\mathbf{F}_{\text {tab }(\boldsymbol{\alpha}=\mathbf{0 . 0 1})}$ \\
\hline Regresi & 3 & 115.39 & 38.463 & 8.893 & 2.867 & 4.377 \\
\hline Residu & 38 & 200.65 & 5.28 & - & - & - \\
\hline
\end{tabular}

Dari tabel 15 di atas dapat dijelaskan bahwa harga $F_{\text {hitung }}$ sebesar 8,893, sedangkan $F_{\text {tabel }}$ dengan $\mathrm{dk}$ pembilang 3 dan $\mathrm{dk}$ penyebut 36 pada taraf signifikan 0,05 adalah 2,87. Ini berarti bahwa persamaan garis regresi $\hat{Y}=36,36$ $+0,160+0,003 X_{2}+0,082 X_{3}$ dapat dipertanggungjawabkan untuk menarik kesimpulan mengenai hubungan antara Motivasi Berprestasi, Kebiasaan Belajar, Penggunaan Media Pembelajaran secara bersama-sama dengan kompetensi guru.

Perhitungan korelasi ganda antara $X_{1^{\prime}} X_{2^{\prime}} \quad X_{3}$ dengan $Y$ memberikan koefisien korelasi sebesar $R_{y 123}=0,652$. Dengan demikian hipotesis penelitian yang 
berbunyi "Terdapat hubungan positif yang signiflkan antara motivasi berprestasi. kebiasaan belajar, dan penggunaan media pembelajaran secara bersamasama dengan kompetensi guru" teruji kebenarannya. Selanjutnya perhitungan koefisien determinasi menunjukan hasil 0,42 , hal ini berarti $42 \%$ variasi yang mempengaruhi kompetensi guru dapat dijelaskan oleh motivasi berprestasi, Kebiasaan belajar, penggunaan media pembelajaran melalui persamaan garis regresi $\hat{Y}$ $=36,36+0,160_{1}+0,003 X_{2}+0,082$ $\mathrm{X}_{3}$.

Selanjutnya, untuk melihat hubungan antara variabel bebas dengan variabel terikat dalam korelasi ganda, dilakukan pengontrolan statistik dengan menggunakan analisis korelasi parsial. Jika variabel Kebiasaan belajar dan penggunaan media pembelajaran dikontrol, maka koefisien korelasi antara motivasi berprestasi dan kompetensi guru sebesar 0,285. Dengan harga $r$ sebesar 0,285 maka dihitung harga $\mathrm{t}$ sebesar $1,786<\mathrm{t}_{\text {tabel }}=$ 2,02 pada taraf signifikansi 0,05 dengan $\mathrm{dk}=38$. Dengan demikian dapat disimpulkan bahwa variabel motivasi berprestasi tidak memiliki hubungan yang signifikan dengan kompetensi guru pada saat variable kebiasaan belajar dan penggunaan media pembelajaran dikontrol.
Jika variabel Motivasi
berprestasi dan penggunaan media pembelajaran dikontrol, maka koefisien korelasi antara Kebiasaan belajar dan kompetensi guru sebesar 0,201. Dengan harga $r$ sebesar 0,201 maka dihitung harga $t$ sebesar $1,232<$ ttabei $=$ 2,02 pada taraf signifikansi 0,05 dengan $\mathrm{dk}=38$. Dengan demikian dapat disimpulkan bahwa variabel Kebiasaan belajar tidak memiliki hubungan yang signifikan dengan kompetensi guru pada saat variabel motivasi berprestasi dan penggunaan media pembelajaran dikontrol.

Jika variabel motivasi berprestasi dan kebiasaan belajar dikontrol, maka koefisien korelasi antara penggunaan media pembelajaran dan kompetensi guru sebesar 0,395. Dengan harga $r$ sebesar 0,395 maka dihitung harga $t$ sebesar $2,584<t$ tabel $=$ 2,02 pada taraf signifikansi 0,05 dengan $\mathrm{dk}=38$. Dengan demikian dapat disimpulkan bahwa variabel penggunaan media pembelajaran memiliki hubungan yang signifikan dengan kompetensi guru pada saat variabel motivasi berprestasi dan Kebiasaan belajar dikontrol.

Rangkuman hasil pengujian analisis korelasi parsial antar variabel penelitian dapat dilihat seperti Tabel 16 di bawah ini: 
Tabel 16. Rangkuman Analisis Korelasi Parsial antara Variabel Bebas dengan Variabel Terikat.

\begin{tabular}{|c|c|c|c|c|c|c|}
\hline Variabel & $\mathbf{N}$ & $\mathbf{r}$ & $\mathbf{r}^{\mathbf{2}}$ & $\mathbf{d k}$ & $\mathbf{t}_{\text {hit }}$ & $\mathbf{T}_{\text {tabel }(\alpha=0,05)}$ \\
\hline$r_{\mathrm{y} 1.23}$ & 40 & 0,285 & 0,081 & 36 & 1,786 & 2,028 \\
\hline$r_{\mathrm{y} 2.13}$ & 40 & 0,201 & 0,040 & 36 & 1,232 & 2,028 \\
\hline$r_{\mathrm{y} 3.12}$ & 40 & 0,399 & 0,156 & 36 & 2,584 & 2,028 \\
\hline
\end{tabular}

\section{Pembahasan}

Dari data yang terkumpul mengenai kompetensi Guru IPA Madrasah Tsanawiyah , diperoleh rentang skor antara 49 sampai dengan 60. Sebanyak 4 orang guru IPA (10\%) memiliki kecenderungan kompetensi baik, 36 orang (90\%) memiliki kecenderungan kompetensi sedang dan tidak ada guru yang memiliki kecenderungan kompetensi yang kurang. Memang hasil penelitian ini belum bisa menjamin kualitas kerja Guru IPA Madrasah Tsanawiyah Se- Sumatera Utara, namun penelitian ini. perlu mendapatkan perhatian yang lebih serius lagi, agar kompetensi guru semakin meningkat, yang muaranya akan meningkatkan mutu pendidikan (out put).

Hasil penelitian menunjukan bahwa terdapat hubungan yang positif antara motivasi berprestasi dengan kompetensi Guru IPA Madrasah Tsanawiyah Se Sumatera Utara. Ini berarti bahwa semakin tinggi motivasi berprestasi seorang guru maka akan menyebabkan semakin tinggi pula kualitas kompetensinya sebagai seorang pengajar dan pendidik. Hal ini bersesuaian dengan pendapat Siagian (1989: 138), menganggap motivasi sebagai daya pendorong yang mengakibatkan seorang mau dan rela menggerakkan semua kemampuan, tenaga, dan waktunya untuk menyelenggarakan berbagai bentuk kegiatan yang menjadi tanggung jawabnya yang wajib dikerjakan dalam rangka pencapaian tujuan serta berbagai sasaran organisasi yang telah ditentukan sebelumnya. Dengan demikian bahwa motivasi berprestasi yang dimiliki oleh seorang. guru umumnya dan guru bidang studi kimia khususnya sangat mendukung untuk meningkatkan kualitas kompetensi guru, Dengan meningkatnya kompetensi guru, diharapkan akan meningkatkan pula mutu pendidikan di Indonesia.

Hasil penelitian selanjutnya menunjukan bahwa terdapat 
hubungan yang positif antara Kebiasaan belajar dengan kompetensi guru IPA Madrasah Tsanawiyah Se Sumatera Utara. Ini berarti bahwa semakin baik kebiasan belajar guru, maka akan semakin baik pula kualitas kompetensinya. Hal ini jelas, dengan Kebiasaan belajar yang baik, guru akan teratur mengatur irama belajarnya. Guru akan selalu berusaha untuk rnenambah wawasan, baik wawasan dalam bidang studi yang digelutinya ataupun wawasan dalam bidang pendidikan secara umum. Hasil penelitian ini juga bersesuaian dengan pandangan dari Harjana (1994) yang menyatakan bahwa : Kebiasaan belajar merupakan cara belajar yang memberikan kepuasan bagi setiap orang yang melakukan aktivitas belajar, sehingga guru atau siapa pun yang terlibat dalam proses aktivitas belajar merasa puas dengan cara-cara belajarnya akan senantiasa mengulangi cara belajar sebelumnya.

Selanjutnya, hasil penelitian ini juga menunjukkan bahwa terdapat hubungan yang positif antara penggunaan media pembelajaran terhadap kompetensi guru IPA Madrasah Tsanawiyah Se Sumatera Utara. Hal ini berarti semakin baik penggunaan media pembelajaran guru di kelas, maka akan semakin baik pula kompetensinya. Media pembelajaran yang digunakan oleh seorang guru bukan harus canggih ataupun mahal, tetapi dilihat bagaimana kemudahan media pembelajaran tersebut untuk transfer pesan dan guru kepada siswanya. Semakin rnudah siswa mengerti suatu pesan pelajaran yang disampaikan guru lewat media pembelajaran maka semakin baik pula media pembelajaran tersebut. Hal ini bersesuaian dengan pendapat dari Shalahuddin, (1986: 18-19) menyatakan media mempunyai fungsi atau peranan untuk menghindari dari hambatan/ gangguan komunikasi dalam proses kegiatan belajar mengajar. Peranan media pengajaran secara garis besar adalah: (1). Menghindari terjadinya verbalisme; (2). Membangkitkan minat/ motivasi; (3).Menarik perhatian murid; (4). Mengaktifkan siswa dalam kegiatan belajar; (5). Mengefektifkan pemberian rangsangan untuk belajar. Jika dilihat dari pandangan tersebut jelas bahwa penggunaan media pembelajaran akan meningkatkan kompetensi guru. Karena banyak hal yang dapat diperoleh dalam penggunaan media di kelas seperti yang tersebut pada 5 (lima) poin sebelumnya. 
Ketiga variabel bebas yakni, motivasi berprestasi, Kebiasaan belajar dan penggunaan media pembelajaran secara bersamasama memiliki hubungan yang positif dengan kompetensi guru IPA Madrasah Tsanawiyah Se Sumatera Utara. Hal ini berarti semakin tinggi motivasi berprestasi, Kebiasaan belajar dan penggunaan media dalam pembelajaran maka akan semakin tinggi pula kualitas kompetensi guru. Temuan penelitian ini sejalan dengan pandangan dari Arikunto (1990) yang menyatakan bahwa ada tiga hal yang mempengaruhi kualitas kompetensi seorang guru, dirnana salah satu di antaranya adalah kemampuan umumnya. Dalarn penelitian ini kemampuan guru dalam menjalankan tugasnya adalah berkaitan dengan kemampuan guru menggunakan media dalam pembelajaran.

\section{PENUTUP}

\section{Simpulan}

Berdasarkan uji hipotesis penelitian, maka dapat ditarik simpulan seperti diuraikan di bawah ini

a. Terdapathubunganyang positif antara motivasi berprestasi dengan kompetensi guru IPA Madrasah Tsanawiyah Se Sumatera Utara. Koefisien korelasi untuk hubungan antara kedua variabel ini adalah sebesar 0,539. Persamaan garis regresi yang diperoleh adalah $\hat{Y}=41,2+0,19 \mathrm{X}_{1}$. Hal ini menunjukkan bahwa semakin tinggi motivasi berprestasi guru maka akan semakin meningkatkan kompetensinya.

b. Terdapat hubungan yang positif antara Kebiasaan Belajar dengan kompetensi guru IPA Madrasah Tsanawiyah Se Sumatera Utara. Koefisien korelasi untuk hubungan antara kedua variabel ini adalah sebesar 0,509. Persamaan garis regresi yang diperoleh adalah $\hat{Y}=44,31+0,1 X_{2}$ $\mathrm{Hal}$ ini menunjukkan bahwa semakin baik kebiasaan belajar guru maka akan semakin meningkatkan kompetensinya.

c. Terdapat hubungan yang positif antara penggunaan media pembelajaran dengan kompetensi guru IPA Madrasah Tsanawiyah Se Sumatera Utara. Koefisien korelasi untuk hubungan antara kedua variabel ini adalah sebesar 0,5485 . Persamaan garis regresi yang diperoleh adalah $\hat{Y}=44,80+0,11 \mathrm{X}_{3}$. Hal ini menunjukkan bahwa semakin baik penggunaan media pembelajaran guru maka akan semakin meningkatkan kompetensinya. 
d. Terdapat hubungan yang positif antara motivasi berprestasi, kebiasaan belajar dan penggunaan media pembelajaran secara bersamasama dengan kompetensi guru IPA Se Sumatera Utara. Koefisien korelasi untuk hubungan antara keempat variabel ini adalah sebesar 0,652 . Persamaan garis regresi yang diperoleh adalah $Y=$ $36,36+0,160 X_{1}+0,003 X_{2}+0,082$ $X_{3}$. Hal ini menunjukkan bahwa semakin baik motivasi berprestasi, kebiasaan belajar dan penggunaan media pembelajaran secara bersamasama maka akan semakin meningkatkan kompetensi guru.

\section{Rekomendasi}

Berdasarkan uraian simpulan di atas, maka yang dapat direkomendasikan antara lain:

a. Kepada Kepala Madrasah dan pengawas kiranya selalu memberikan contoh, pengarahan kepada para guru untuk selalu meningkatkan kompetensinya, karena kompetensi yang baik akan bermuara kepada peningkatan mutu hasil pendidikan (output). Kepala Madrasah hendaknya melengkapi sarana dan prasarana sekolahnya, sehingga guru tidak kesulitan untuk menyediakan segala jenis media pembelajaran yang dapat meningkatkan kualitas kompetensinya.

b. Kementerian Agama/Kanwil terkait selalu memberikan penataran, lokakarya, workshop, ataupun segala jenis kegiatan yang dapat meningkatkan kompetensi guru. Kompetensi guru merupakan satu faktor yang dapat mempengaruhi mutu pendidikan. Mutu pendidikan bukanlah hanya tanggung jawab guru semata, tetapi tanggungjawab seluruh praktisi pendidikan.

c. Kepada guru, untuk selalu meningkatkan motivasinya dalam menjalankan tugas pendidik dan pengajar, agar dapat dilaksanakan proses pembelajaran secara lebih baik. Kompetensi yang baik akan meningkatkan memberikan kontribusi yang positif kepada peningkatan mutu lulusan suatu sekolah. Guru dalam melaksanakan pembelajaran di kelas hendaknya selalu menggunakan media pembelajaran, karena media pembelajaran jelas akan meningkatkan kompetensinya, serta siswa akan lebih tertarik dan lebih mudah untuk mengikuti materi pelajaran.

d. Penelitian ini hanya mengungkapkan tiga 
faktor yang mempengaruhi kompetensi guru, yaitu variabel motivasi berprestasi, Kebiasaan belajar dan penggunaan media pendidikan. Sebenarnya masih banyak faktor lain yang mempengaruhinya, oleh sebab itu kepada para peneliti lain dapat melihat aspek lain yang mempengaruhi aspek kompetensi guru.

\section{DAFTAR PUSTAKA}

Aqib, Zainal (2002). Profesionalisme Guru Dalam Pembelajaran, Surabaya: Insan Cendikia.

Arikunto, Suharsimi (1993). Prosedur Penelitian, Suatu Pendekatan Prakiek, Jakarta: PT Rineka Cipta.

Atkitson, Rita L, dkk (1993). Pengantar Psikologi, Terjemahan Nuijarmah Taufik, Jakarta: Erlangga.

Brigss, Leslie (1970). Principles of Instructional Design, New York: Holt, Rinehart, and Winston.

Gagne, Robert M. (1970). Principles of Instructional Design, New York: Holt, Rinehart, and Winston.

Harjana, A.M. (1994). Kiat Sukses di Perguruan Tinggi, Yogyakarta: Kanisius. Harper and Crow, Lester, D., (1960). An Introduction to Guidance. New York.

Maslow, Abraham H. (1994). Motivasi dan Kepribadian: Teori Motivasi dengan Pendekatan Hierarki Kebutuhan Manusia, Terjemahan Sen Manajemen, Jakarta: Pustaka Binaman Pressindo.

Sardinian, S. Arief, dkk., (2003). Media Pendidikan, Jakarta: Rajagrafindo Persada.

Shalahuddin, Mahfudh (1986). Media Pendidikan, Surabaya: PT Bina Ilmu

Siagian, Sondang P. (1989). Teori Motivasi dan Aplikasinya, Jakarta: Bina Aksara.

Soetjipto dan Raflis Kosasi (2000) Profesi Keguruan, Jakarta: Rineka Cipta.

Suhartono, Budi (2003). Kontribusi Pengarahan Kepa/a Sekolah dan Motivasi Berprestasi Terhadap Kinerja Guru Bimbingan Konseling di madrasah Tsanawiyah Kota Medan, Thesis, Universitas Negeri Medan. 
Surakhmad, Winarno (1994). Pengantar Interaksi Belajar Mengajar, Bandung: Tarsito.

Tilaar, H. A.R. (2002). Membenahi Pendidikan Nasional, Jakarta: Rineka Cipta.

Undang-Undang Republik Indonesia Nomor 20 Tahun 2003 tentang Sistem Pendidikan Nasional (Sisdiknas), Bandung: Fokusmedia, 2003. 